\title{
Development of flexible ceramic-glass seals for intermediate temperature planar solid oxide fuel cell
}

\author{
Wei Zhang, Xiaopeng Wang, Dong Yan, JiaJun Yang, Jian Pu', Bo Chi, Li Jian
}

\begin{abstract}
School of Materials Science and Engineering, State Key Laboratory of Material Processing and Die \&Mould Technology, Huazhong University of Science \& Technology, Wuhan, Hubei 430074, PR China
\end{abstract}

\begin{abstract}
The ceramic-glass was employed as the most commonly used seal materials in planar solid oxide fuel cell (SOFC). In this study, a novel glass with relative low glass soft temperature was added into $\mathrm{Al}_{2} \mathrm{O}_{3}$ powders to form ceramic-glass composite seals by tape casting technique. Based on the tested result of gas tightness and compressibility, it was found that the seals with $40 \mathrm{wt} \%$ glass exhibited excellent seal performance at the leakage rates of only $0.01 \mathrm{sccm} . \mathrm{cm}^{-1}$ under gas pressure of $10.2 \mathrm{kPa}$, and compressive load of $0.17 \mathrm{MPa}$ at $750{ }^{\circ} \mathrm{C}$. The seals showed the desired thermal cycle stability at low leakage rates within 10 thermal cycles. It can be observed that the deformability of seals sharply increase when the glass contents was higher than 30 $w t \%$. Microstructural analysis of the seals also exhibited very good interfaces bondage and chemical compatibility which was in good agreement with gas tightness prediction for the flexible ceramic-glass seals model. The seals have been applied in large size cell test to confirm its applicability in SOFC.
\end{abstract}

Key words: Solid oxide fuel cell, Ceramic-glass seal, Leakage rates, Thermal cycle stability, Deformability

Corresponding author. Tel.: +86 27 87558142; fax: +86 2787558142 .

E-mail address: pujian@hust.edu.cn (Jian Pu). 


\section{Introduction}

Solid oxide fuel cell (SOFC) has been developed during the past decade for a wide range of application including stationary plant and portable power [1]. As one of two different SOFC stack designs, the planar SOFC provides higher energy conversion efficiency and low manufacture cost. However, it was also confronted crucial challenge on the leakage rate and thermal cycle stability under SOFC operation temperature [2-5]. The gas leakage may reduce fuel utilization, which directly results in the damage of SOFC stack. Many researchers have made a lot of efforts to develop sealing materials, which approximately includes compressive and rigid seals [3, 6-8]. A principal advantage of compressive seals is to reduce the requirement for matching thermal expansion coefficients (CTE). Considering that the major leakage paths are locating on interface between the seals and cell/interconnect, the compressive seal should be able to achieve reliable sealing effect under extremely high compressive load [9-12]. For example, mica sheets can decrease leakage rates to lower than 0.1 $\mathrm{sccm} / \mathrm{cm}$ under 0.7 MPa compressive loads [3]. $\mathrm{Al}_{2} \mathrm{O}_{3}$-based compressive seals also have been developed by tape casting and showed an excellent performance in SOFC application [13].

Glass-based materials were considered as the most reliable seals because the chemical composition of glass was designed to meet most of seal requirements such as adherence, chemical stability, electrical insulation, and CTE match [5, 6, 13]. Additionally, a good glass-based seals should have suitable viscosity to maintain the mechanical strength at high temperature [14]. Two approaches have been employed for improving structural strength of seals. One of that is the volume fraction of crystalline phase was obtained from glass matrix such as $\mathrm{BaO}-\mathrm{CaO}-\mathrm{SiO}_{2}$, $\mathrm{AO}-\mathrm{Al}_{2} \mathrm{O}_{3}-\mathrm{SiO}_{2}-\mathrm{B}_{2} \mathrm{O}_{3}$ glass system $(\mathrm{A}=\mathrm{Ba}, \mathrm{Ca}, \mathrm{Mg})$ [15]. But the crystallization kinetics of the glass is difficult to be controlled due to high temperature gradation inside of stack. Besides, it is also a problem that the formation of some crystalline phase can generate CTE mismatch. The other is that glass-ceramic seals are prepared by the addition of different oxides into glass powders including $\mathrm{Al}_{2} \mathrm{O}_{3}, \mathrm{TiO}_{2}, \mathrm{ZrO}_{2}$ to 
overcome inherent brittleness and crack growth from glass[16]. Recently studies have demonstrated that the leakage rate and thermal cycle stability have been significantly improved by adding glass into compressive seals materials such as mica and $\mathrm{Al}_{2} \mathrm{O}_{3}$ powders [17-19]. The leakage paths were minimized by infiltrating the voids volume with glass-based powders, and wetting the adjoining interface while ceramic powders provide the framework in sealant structure. It is very important that the glass has appropriate soft temperature and slow crystallization rate to obtain flexible seals at SOFC operation temperature.

In the present work, a special glass was chosen as seals because it has relative low soft temperature and high devitrification resistance after long time operation at $750^{\circ} \mathrm{C}$. The $\mathrm{Al}_{2} \mathrm{O}_{3}$-glass composite seals have been developed by tape casting technique. The purpose of this study is to lower the seals' leakage, improve the thermal cycle stability, deformability, and chemical compatibility of the sealant by optimize the proportion of $\mathrm{Al}_{2} \mathrm{O}_{3}$ and glass.

\section{Experimental}

\subsection{Materials and preparation}

A glass was obtained in the form of powder from a commercial vendor (San Le Company, China), with composition: $\mathrm{SiO}_{2}: 64.74 \mathrm{~mol} \%, \mathrm{Al}_{2} \mathrm{O}_{3}: 3.4 \mathrm{~mol} \%, \mathrm{TiO}_{2}: 6.66$ $\mathrm{mol} \%, \mathrm{~K}_{2} \mathrm{O}_{3}: 9.8 \mathrm{~mol} \%, \mathrm{Na}_{2} \mathrm{O}: 11.45 \mathrm{~mol} \%, \mathrm{MnO}: 3.95 \mathrm{~mol} \%$. This glass powder named as DT4 has an average particle size of 1 2 $\mu \mathrm{m}$. Fig.1 showed the micrographs of the glass and $\mathrm{Al}_{2} \mathrm{O}_{3}$ powder (average size $1 \sim 5 \mu \mathrm{m}$, Almatis, USA). The DT4 glass has soft temperature of $620{ }^{\circ} \mathrm{C}$ and CTE of $9.2 \times 10^{-6} / \mathrm{k}$ from room temperature to 300 ${ }^{\circ} \mathrm{C}$. The $\mathrm{Al}_{2} \mathrm{O}_{3}$-glass seals were prepared by tape casting with different proportion of glass and $\mathrm{Al}_{2} \mathrm{O}_{3}$ mixture. The weight ratio of $\mathrm{Al}_{2} \mathrm{O}_{3}$ and glass was 50:50, 60:40, 70:30, 80:20, 90:10 which was named as AD50, AD40, AD30, AD20, AD10 respectively. The $\mathrm{Al}_{2} \mathrm{O}_{3}$-glass tapes with thickness of $0.3 \mathrm{~mm}$ were fabricated after drying at room temperature. Square window frame with an outside dimension of $70 \times 70 \mathrm{~mm}$ and 
inside $50 \times 50 \mathrm{~mm}$ were cut from the seal tapes for leakage rates test.

\subsection{Leakage rates measurement}

Fig.2 showed the graph of thermogravimetric analysis in air for AD40 and AD30 seals from room temperature to $800{ }^{\circ} \mathrm{C}$ with heating rate of $10{ }^{\circ} \mathrm{C} / \mathrm{min}$, which was carried out in the thermal analysis system (STA449F3, Retsch Inc, Germany). It can be seen that the mass of sample was gradually decreased from 200 to $450{ }^{\circ} \mathrm{C}$, originating from some organic additives volatilized from the seals tape. The temperature program for leakage rates test was set as shown in Fig.3 according to thermal analysis result. The heating rate was $2{ }^{\circ} \mathrm{C} / \mathrm{min}$, from room temperature to 200 ${ }^{\circ} \mathrm{C}$, and dwelled at $200{ }^{\circ} \mathrm{C}$ for $90 \mathrm{~min}$, then $1{ }^{\circ} \mathrm{C} / \mathrm{min}$ from $200{ }^{\circ} \mathrm{C}$ to $450{ }^{\circ} \mathrm{C}$, and also dwelled $90 \mathrm{~min}$ at $450{ }^{\circ} \mathrm{C}$, followed by further heating at $2{ }^{\circ} \mathrm{C} / \mathrm{min}$ up to testing temperature of $750{ }^{\circ} \mathrm{C}$ for $120 \mathrm{~min}$. In order to evaluate the thermal cycle stability of seals, the sample was cooled to $300{ }^{\circ} \mathrm{C}$ to initiate thermal cycling, then rapidly heated from 300 to $750{ }^{\circ} \mathrm{C}$ with heating rate of $2{ }^{\circ} \mathrm{C} / \mathrm{min}$, dwelled at $750{ }^{\circ} \mathrm{C}$ for $120 \mathrm{~min}$. The leak rates testing system used for seals as shown in Fig.4, and the principle has been described in Ref.[20]. A precise flow meter with an accuracy of $0.001 \mathrm{sccm} . \mathrm{cm}^{-1}$ was chosen to measure the leakage rates with $\mathrm{N}_{2}$ as testing gas. The leakage rates were tested under different compressive load and input gas pressure.

\subsection{Microstructural characterization}

The samples were obtained from the tested seals for the observation of its surface morphology and cross section. The samples for the cross section examination were mounted in a Buhler epoxide and polished on a Buhler automatic polisher. A Quanta 200 scanning electron microscope (SEM) with energy disperse spectroscopy (EDS) attachment was used for the microstructural characterization of tested seals. The interconnect alloy (SUS 430) and cell anode (NiO+YSZ) were chosen as adjacent components to examine the joint interface and chemical compatibility of seal which was performed under compressive load of $0.17 \mathrm{MPa}$ at $750{ }^{\circ} \mathrm{C}$ for $100 \mathrm{~h}$. The crystalline phase of the $\mathrm{Al}_{2} \mathrm{O}_{3}$-glass seals was identified by X-ray diffraction (X'Pert PRO, PAN alytical B.V.) after dwelled $750{ }^{\circ} \mathrm{C}$ for $50 \mathrm{~h}$. The relationship between 
deformability of the $\mathrm{Al}_{2} \mathrm{O}_{3}$-glass seals and the weight fraction of glass was determined at $750{ }^{\circ} \mathrm{C}$ under compressive load of $0.17 \mathrm{MPa}, 0.27 \mathrm{MPa}, 0.54 \mathrm{MPa}$ using a cylindrical rod configuration (diameter of $25 \times 10 \mathrm{~mm}$ ). Detailed information about test principle and equipment was described in Ref.[18].

\subsection{Cell performance test}

The open circuit voltage (OCV) and performance of cell were tested as detector to investigate the applicability of sealant. The tape casting - screen printing - sintering processes were used for fabrication of anode supported planar SOFC cells with size of $110 \times 110 \mathrm{~mm}^{2}$, and the active area of cell was $90 \times 90 \mathrm{~mm}^{2}$. The cell was sealed at the periphery on anode and cathode sides by window-frame shaped AD40 seal tape and mica respectively which pure hydrogen and dry air were fed as the fuel and oxidant. The performance and degradation rate of cell were tested at $750{ }^{\circ} \mathrm{C}$, associating with the gas tightness of the sealant. Furthermore, the tested cell configuration was disassembled to examine possible gas leakage paths.

\section{Results and discussion}

\subsection{Design of flexible ceramic-glass seals}

The ceramic-glass seals materials have excellent joint properties between metal and ceramic. Differing from regularly glass contained seals, a novel ceramic-glass seal structure was designed to provide lower leakage rates and reasonable deformation ability, as shown in Fig.5. The $\mathrm{Al}_{2} \mathrm{O}_{3}$ particles were chosen as support framework, and the relative fine glass powders were dispersed among $\mathrm{Al}_{2} \mathrm{O}_{3}$ particles as packing materials, in which the glass has relative low glass soften temperature $\left(T_{s}\right)$. When the operation temperature is lower than $\mathrm{T}_{\mathrm{s}}$ of glass, it is isolated and dispersed among $\mathrm{Al}_{2} \mathrm{O}_{3}$ particles. Similar with the compressive seals, the gas may be mainly leaked from the interface of seals [20-22]. With the temperature elevated to higher than $T_{\mathrm{s}}$ of glass, the initial low viscosity of the glass particle provides good fluidity to pores among $\mathrm{Al}_{2} \mathrm{O}_{3}$ particles, in which the $\mathrm{Al}_{2} \mathrm{O}_{3}$ particles is connected each other by the soften glass, so the inside pores of seals become much less. When the SOFC operation 
temperature is reached, a glass can be wetted and bonded to generate well sealing interface, and eliminate the leakage paths of gas. Furthermore, the flexible seals can reduce the thermal stress, and improve long term thermal cycle stability.

\subsection{Leakage rate and deformability of composite seals}

The composite seals with different DT4 glass content were tested for leakage rates of gas under compressive load of $0.17 \mathrm{Mpa}$ at $750{ }^{\circ} \mathrm{C}$. Different gas pressure requirement are desired for real stack operation to enhance the reliability of seals, thus the input gas pressure was increased from $3.4 \mathrm{kPa}$ to $20.4 \mathrm{kPa}$. The results of the measured leakage rate were shown in Fig.6. The leakage rates basically remained stable with gas pressure varied from $3.4 \mathrm{kPa}$ to $10.2 \mathrm{kPa}$ which is usual gas pressure on SOFC operation. The initial leakage rate was $0.02 \mathrm{sccm} . \mathrm{cm}^{-1}$ for AD10 seal, about $0.02 \mathrm{sccm} . \mathrm{cm}^{-1}$ lower than the SECA standard with leakage rate of $0.04 \mathrm{sccm} . \mathrm{cm}^{-1}$. When the glass content of seals reached to $30 \mathrm{wt} \%$ (AD30 seal), the leakage rates was gradually dropped to $0.01 \mathrm{sccm} . \mathrm{cm}^{-1}$. Similar results were also observed on AD40 and AD50 seal. It is noted that improvement of gas tightness may have a limit with glass content increase in composite seals. Moreover, when the gas pressure was varied from $10.2 \mathrm{kPa}$ to $21 \mathrm{kPa}$, the leakage rates were rapidly increased to higher than 0.04 sccm.cm ${ }^{-1}$ for AD10, AD20 and AD30 seals. But different behavior in that the leakage rates maintained slowly increase, lowering than $0.02 \mathrm{sccm} . \mathrm{cm}^{-1}$ for AD40 and AD50 seals. It is obvious that the presence of DT4 glass can enhance the gas tightness of $\mathrm{Al}_{2} \mathrm{O}_{3}$-glass composite seals in which the glass may eliminate some leakage paths by blocking pores and wet interface when tested temperature was higher than the $T_{\mathrm{s}}$ of the glass. The leakage characteristic of ceramic-glass seal can be described according to the model conducted by Fig.5.

Considering the fact that compressive load of the seals has effectively influence on gas tightness, the different compressive load was applied on the AD40 seals to measure the leakage rates at $750{ }^{\circ} \mathrm{C}$, as shown in Fig.7. With the compressive load increased from 0.17 $\mathrm{MPa}$ to $0.54 \mathrm{MPa}$, the leakage rates were decreased from 0.01 $\mathrm{sccm} . \mathrm{cm}^{-1}$ to $0.005 \mathrm{sccm} . \mathrm{cm}^{-1}$ with gas pressure of $10.2 \mathrm{kPa}$. The results illustrates 
that the ceramic-glass seals present well interface combination with adjacent components under higher compressive load which has been proved on mica-based and $\mathrm{Al}_{2} \mathrm{O}_{3}$-based compressive seals[23-25]. Because of the limitation from compressive strength of cell, the compressive load should be chosen on suitable range for seal.

Fig. 8 is the microstructure of fracture surface for four seals under compressive load of $0.17 \mathrm{MPa}$ after $750{ }^{\circ} \mathrm{C}$ heating treatment. It was concluded that DT4 glass becomes more soft and flowable at $750{ }^{\circ} \mathrm{C}$, since its $\mathrm{T}_{\mathrm{s}}$ temperature of this glass is around $620^{\circ} \mathrm{C}$. Based on the microstructural analysis, it could be seen that the seal was gradually densified with the glass content increased from $10 \mathrm{wt} \%$ to $50 \mathrm{wt} \%$, flowable glass calked pores among $\mathrm{Al}_{2} \mathrm{O}_{3}$ particles. When the glass content was lower than $30 \mathrm{wt} \%$ in composite seals, the volume of glass was not enough to fill full of pores, thus the gas may be leaked from network of $\mathrm{Al}_{2} \mathrm{O}_{3}$ particles or interface. However, the microstructure of AD40 and AD50 have little difference and it was hardly observed on open pores in AD40 and AD50 seals, which is corresponded to good gas tightness. The proportion of glass and $\mathrm{Al}_{2} \mathrm{O}_{3}$ particles should be optimized to avoid excessive glass fluidity at high temperature, owing to low soft temperature of the glass. X-ray diffraction of five seals heat treated at $750{ }^{\circ} \mathrm{C}$ for $50 \mathrm{~h}$ are shown in Fig.9. It can be detected small amount of crystal phase $\mathrm{Al}_{2} \mathrm{SiO}_{5}$ and $\mathrm{KAlSi}_{3} \mathrm{O}_{8}$ belonging to rhombic crystalline system were appeared, besides $\mathrm{Al}_{2} \mathrm{O}_{3}$ phase in composite seals. Because the amount of crystalline phase originating from glass is little, the glass can keep relatively thermal stability under the high devitrification resistance, when operated at $750{ }^{\circ} \mathrm{C}$. Generally, the kinetic of crystallization in glass should be suppressed because the crystalline phases may bring some problems such as thermal stability and CTE mismatch. The effect of crystalline phase on glass based seals has been discussed in some literatures [26-29]. As the result of phase identification and micrograph, the AD40 seal was considered as a suitable candidate for SOFC application.

It is desirable for seals to remain deformability under high temperature which can decrease the contact resistance between current collector and electrode of cell. Fig. 10 showed the deformation of different seals after heat treated for $2 \mathrm{~h}$ at $750{ }^{\circ} \mathrm{C}$ 
under different compressive load of $0.17 \mathrm{MPa}, 0.27 \mathrm{MPa}, 0.54 \mathrm{MPa}$. When $30 \mathrm{wt} \%$ glass added into $\mathrm{Al}_{2} \mathrm{O}_{3}$, the deformability of sample was obviously improved owing to the reduction of its high temperature viscosity. When the compressive pressure is overlarge, the glass would expand so the stress can't be calculated and copared especially the glass content is too much, so deformation for AD50 under compressive load of $0.27 \mathrm{MPa}, 0.54 \mathrm{MPa}$ at $750{ }^{\circ} \mathrm{C}$ is not provided.The soften glass can properly connect of adjacent components and release the thermal stress originating from CTE mismatch. This similar experimental result was also described on other ceramic-glass composite seals[18, 19]. It is noted that the seals showed similar deformability with compressive load increased from $0.17 \mathrm{MPa}$ to $0.54 \mathrm{Mpa}$, which imply that the framework of $\mathrm{Al}_{2} \mathrm{O}_{3}$ play the important role on maintaining deformability of composite seals.

\subsection{Thermal cycling and interface characteristic of seals}

The optimized composite seals AD40 were also tested for long term thermal cycles under different input gas pressure, and compressive load of $0.17 \mathrm{MPa}$ at $750{ }^{\circ} \mathrm{C}$. The relationship between leakage rates and number of thermal cycles was shown in Figure.11. The initial leakage rate was close to zero under input gas pressure of 3.4 $\mathrm{kPa}$. The leakage rate was slowly increased to $0.005 \mathrm{sccm} . \mathrm{cm}^{-1}$ after 10 thermal cycles. It is known from earlier studies that some micro crack may be produced in sealing interface because the thermal stress can be occurred during thermal cycling. But the leakage rate can be limited at a constant value which has been demonstrated by gas diffusion model [30]. It is important that the leakage rate maintained at relative low value even if the gas pressure was increased to $20.4 \mathrm{kPa}$ for AD40 seals. The seals showed similar thermal cycle stability within 10 thermal cycles, but different behavior in that the initial leakage rate was gradually enlarged with gas pressure increased. However, the leakage rate of the seals was always lower than $0.03 \mathrm{sccm} . \mathrm{cm}^{-1}$, even the gas pressure has reached to $20.4 \mathrm{kPa}$ after 10 thermal cycles. The excellent gas tightness can be attributed to flexible glass interface seal layer which can effectively reduce the stress concentration.

Fig.12 showed the micrographs of AD40 seal interface adjoined with SUS 430 
alloy and anode of cell, respectively. It can be observed that no obvious cracks and pore on interfaces or inside of seals. The relative low soften temperature could be considered as a potential reason for this glass. On the other hand, the $\mathrm{Al}_{2} \mathrm{O}_{3}$ framework can provide enough strength to maintain the shape of seals. Interface bondage also showed good agreement with low leakage rate measurement. Additional investigation was performed to determine the interface chemical compatibility. It is obvious that the seals have no elements diffusion and chemical reaction between the adjacent components by examining EDS line, suggesting that the AD40 seal was chemical stable operated on SOFC temperature. After dwelled $750{ }^{\circ} \mathrm{C}$ for $50 \mathrm{~h}$, however, it cannot be observed on new crystalline phases in Fig.9 of seals. It may be explained that the alkali element in DT4 glass increase the difficult of crystallization [23]. Therefore, AD40 composite seal has the potential application at SOFC operation temperature.

The alkaline metals $\mathrm{K}, \mathrm{Na}$ in DT4 play an important role of network modifiers, which can affect the glass Tg,Ts and CTE. But alkaline metal were reactive with stainless metal alloy including chromium and form much volatile species such as $\mathrm{Na}_{2} \mathrm{CrO}_{4}(\mathrm{~g})$ and $\mathrm{K}_{2} \mathrm{CrO} 4(\mathrm{~g})[6]$. The presence of $\mathrm{Na}$ or $\mathrm{K}$ in sealants was noted to enhance the chromium vaporization from metallic interconnects and chromium ends up in the air electrode and blocks active sites[8]. This paper only discusses the sealing performance and mechanism of the ceramic-glass composite seals, the volatilization and poisoning effect on the stability of SOFCs need further study.

\subsection{Investigation of cell performance by using AD40 seals}

In order to evaluate the performance of AD40 seals on SOFC, single cell was configured when the seals was used on anode side. The current-voltage characteristics of single cell were measured at $750{ }^{\circ} \mathrm{C}$, as shown in Fig.13. The open circuit voltage $(\mathrm{OCV})$ in the test is $1.14 \mathrm{~V}$ which is close to theoretical voltage value of $1.23 \mathrm{~V}$. According to the Nernst equation associating with gas partial pressure and voltage, the measured OCV could be used to estimate the leakage rates[31]. The power density of cell was nearly 0.7 W.cm ${ }^{-2}$ with current density of $1.2 \mathrm{~A} . \mathrm{cm}^{-2}$. The high performance of cell implied good interface contact because of high temperature 
deformation of the AD40 seals. The gas leakage was main reason resulting to cell performance degradation. The time dependent degradation of cells used AD40 as anode seals was performed with the constant discharge current density of $0.37 \mathrm{~A} . \mathrm{cm}^{-2}$, the voltage degradation rate decrease steadily to $15 \mathrm{mV}$ during the initial $50 \mathrm{~h}$, then reaches a stable voltage value of $0.825 \mathrm{~V}$ for $50 \mathrm{~h}$, as shown in Fig.14. The initial voltage degradation may mainly originate from thermal stability of interface contact layer, other than interface seal failure. From the results of post test analysis, there are no traces of hydrogen leakage on seal interface. Thus, it can be concluded that the $\mathrm{AD} 40$ seals can meet restrictive requirements for SOFC application.

\section{Conclusion}

An $\mathrm{Al}_{2} \mathrm{O}_{3}$ based composite seals were fabricated by tape casting technique. The effect of glass content was investigated on leakage rates and deformability. The optimized AD40 seals demonstrated an excellent gas tightness, thermal mechanical property and chemical compatibility, in which the leakage rates of $0.01 \mathrm{sccm} . \mathrm{cm}^{-1} \mathrm{can}$ be reached with gas pressure of $10.2 \mathrm{kPa}$ at $750{ }^{\circ} \mathrm{C}$. The seals showed high thermal cycle stability after 10 thermal cycles of up to $750{ }^{\circ} \mathrm{C}$. Furthermore, with the seals adopted on cell test, it is also confirmed that the large size cell reached to OCV of $1.14 \mathrm{~V}$ and power density of $0.7 \mathrm{~W} . \mathrm{cm}^{-2}$, maintained stable voltages under current density of $0.37 \mathrm{~A} \mathrm{~cm}^{-2}$ for $50 \mathrm{~h}$.

\section{Acknowledgements}

This research was financially supported by National Science Foundation of China under contract 50572099. The SEM and XRD characterizations were assisted by the Analytical and Testing Center of Huazhong University of Science and Technology.

\section{Reference}

[1] Minh NQ. Solid oxide fuel cell technology_features and applications. Solid State lonics 2004;174:271-7.

[2] Singhal SC. Solid oxide fuel cells for stationary, mobile, and military applications. Solid State Ionics 2002;152:405-10. 
[3] Simner SP, Stevenson JW. Compressive mica seals for SOFC applications. Journal of Power Sources 2001;102:310-6.

[4] Smeacetto F, Chrysanthou A, Salvo M, Zhang Z, Ferraris M. Performance and testing of glass-ceramic sealant used to join anode-supported-electrolyte to Crofer22APU in planar solid oxide fuel cells. Journal of Power Sources 2009;190:402-7.

[5] Kumar V, Pandey O, Singh K. Thermal and crystallization kinetics of yttrium and lanthanum calcium silicate glass sealants for solid oxide fuel cells. international journal of hydrogen energy 2011;36:14971-6.

[6] Fergus JW. Sealants for solid oxide fuel cells. J. Power Sources 2005;147:46-57.

[7] Liu W, Sun X, Khaleel MA. Predicting Young's modulus of glass/ceramic sealant for solid oxide fuel cell considering the combined effects of aging, micro-voids and self-healing. Journal of Power Sources 2008;185:1193-200.

[8] Lessing PA. A review of sealing technologies applicable to solid oxide electrolysis cells. Journal of Materials Science 2007;42:3465-76.

[9] Punbusayakul N, Boonsiri K, Charojrochkul S, Fungtammasan B, Charoensuk J. Assessment on hermetic property and mechanical compatibility of various groove-gasket sealing designs for solid oxide fuel cell stack. Journal of Power Sources 2012;213:186-202.

[10] Rautanen M, Himanen O, Saarinen V, Kiviaho J. Compression Properties and Leakage

Tests of Mica-Based Seals for SOFC Stacks. Fuel Cells 2009;9:753-9.

[11] Le S, Sun K, Zhang N, An M, Zhou D, Zhang J, Li D. Novel compressive seals for solid oxide fuel cells. Journal of power sources 2006;161:901-6.

[12] Litzelman S, Hertz J, Jung W, Tuller H. Opportunities and challenges in materials development for thin film solid oxide fuel cells. Fuel Cells 2008;8:294-302.

[13] Lin C-K, Chen J-Y, Tian J-W, Chiang L-K, Wu S-H. Joint strength of a solid oxide fuel cell glass-ceramic sealant with metallic interconnect. Journal of Power Sources 2012;205:307-17. [14] Chang H-T, Lin C-K, Liu C-K. High-temperature mechanical properties of a glass sealant for solid oxide fuel cell. Journal of Power Sources 2009;189:1093-9.

[15] Lahl N, Singh K, Singheiser L, Hilpert K, Bahadur D. Crystallisation kinetics in AO-Al2O3-SiO2-B2O3 glasses ( $\mathrm{A}=\mathrm{Ba}, \mathrm{Ca}, \mathrm{Mg})$. Journal of Materials Science 2000;35:3089-96.

[16] Bram M, Reckers S, Drinovac P, Mönch J, Steinbrech RW, Buchkremer HP, Stöver D. Deformation behavior and leakage tests of alternate sealing materials for SOFC stacks. Journal of Power Sources 2004;138:111-9.

[17] Chou Y-S, Stevenson JW. Mid-term stability of novel mica-based compressive seals for solid oxide fuel cells. Journal of Power Sources 2003;115:274-8.

[18] Wang X, Yan D, Fang D, Luo J, Pu J, Chi B, Jian L. Optimization of Al 2 O 3-glass composite seals for planar intermediate-temperature solid oxide fuel cells. Journal of Power Sources 2013;226:127-33.

[19] Ye Y, Yan D, Wang X, Pu J, Chi B, Jian L. Development of novel glass-based composite seals for planar intermediate temperature solid oxide fuel cells. International Journal of Hydrogen Energy 2012;37:1710-6.

[20] Sang S, Li W, Pu J, Jian L. Novel Al2O3-based compressive seals for IT-SOFC applications. Journal of Power Sources 2008;177:77-82. 
[21] Sang S, Jian P, Jiang S, Li J. Prediction of H2 leak rate in mica-based seals of planar solid oxide fuel cells. Journal of Power Sources 2008;182:141-4.

[22] Dai Z, Pu J, Yan D, Chi B, Jian L. Thermal cycle stability of Al 2 O 3-based compressive seals for planar intermediate temperature solid oxide fuel cells. International Journal of Hydrogen Energy 2011;36:3131-7.

[23] Mahapatra M, Lu K. Glass-based seals for solid oxide fuel and electrolyzer cells-a review. Materials Science and Engineering: R: Reports 2010;67:65-85.

[24] Chou YS, Stevenson JW, Singh P. Thermal cycle stability of a novel glass-mica composite seal for solid oxide fuel cells: Effect of glass volume fraction and stresses. Journal of Power Sources 2005;152:168-74.

[25] Zhang W, Yan D, Duan J, Pu J, Chi B, Li J. Development of Al2O3/glass-based multi-layer composite seals for planar intermediate-temperature solid oxide fuel cells. International Journal of Hydrogen Energy 2013;38:15371-8.

[26] Goel A, Pascual MJ, Ferreira JMF. Stable glass-ceramic sealants for solid oxide fuel cells: Influence of Bi2O3 doping. International Journal of Hydrogen Energy 2010;35:6911-23.

[27] Reddy AA, Tulyaganov DU, Goel A, Sardo M, Wiper PV, Pascual MJ, Kharton VV, Kolotygin VA, Tsipis EV, Mafra L. Melilite glass-ceramic sealants for solid oxide fuel cells: effects of ZrO2 additions assessed by microscopy, diffraction and solid-state NMR. J.mater.chem.a 2013;1:6471-80.

[28] Rezazadeh L, Baghshahi S, Golikand AN, Hamnabard Z. Structure, phase formation, and wetting behavior of $\mathrm{BaO}-\mathrm{SiO} 2-\mathrm{B} 2 \mathrm{O} 3$ based glass-ceramics as sealants for solid oxide fuel cells. Ionics 2014;20:55-64.

[29] Ghosh S, Sharma AD, Mukhopadhyay AK, Kundu P, Basu RN. Effect of BaO addition on magnesium lanthanum alumino borosilicate-based glass-ceramic sealant for anode-supported solid oxide fuel cell. International Journal of Hydrogen Energy 2010;35:272-83.

[30] Sang S, Jian P, Chi B, Li J. Model-oriented cast ceramic tape seals for planar solid oxide fuel cells. Journal of Power Sources 2009;193:723-9.

[31] Chou YS, Stevenson JW. Long-Term Thermal Cycling of Phlogopite Mica-Based Compressive Seals for Solid Oxide Fuel Cells. Journal of Power Sources 2005;140:340-5. 
Fig.1. SEM micro morphology of (a) $\mathrm{Al}_{2} \mathrm{O}_{3}$ powder and (b) DT4 glass used for fabrication of composite tape seals.

Fig.2. Thermogravimetric graph of the tape cast AD40 and AD30 samples.

Fig.3. The heat treatment schedule for leakage rates and thermal cycles test.

Fig.4. The schematic of the leakage rates test system.

Fig.5. The schematic of $\mathrm{Al}_{2} \mathrm{O}_{3}$-glass composite seals operated at different temperature.

Fig.6. Leakage rates of the seals under different input gas pressure, compressive load $0.17 \mathrm{MPa}$ at $750^{\circ} \mathrm{C}$.

Fig.7. Leakage rates of the AD 40 seals under different compressive load, input gas pressure from 3.4 to $20.4 \mathrm{Kpa}$ at $750{ }^{\circ} \mathrm{C}$.

Fig.8. Microstructure of fracture surface for seals under compressive load of 0.17 $\mathrm{MPa}$ at $750^{\circ} \mathrm{C}$, (a) AD 10, (b) AD 20, (c) AD 30, (d) AD 40,(e) AD 50.

Fg.9. XRD pattern of $\mathrm{Al}_{2} \mathrm{O}_{3}$-based seals with different glass content, heat treated at $750{ }^{\circ} \mathrm{C}$ for $50 \mathrm{~h}$.

Fig.10. Deformation for $\mathrm{Al}_{2} \mathrm{O}_{3}$-based seals with different glass content under compressive load of $0.17 \mathrm{MPa}$ at $750{ }^{\circ} \mathrm{C}$.

Fig.11. The relationship between leakage rates and thermal cycles for the AD40 seals, compressive pressure of $0.17 \mathrm{MPa}$ and input gas pressure from 3.4 to $20.4 \mathrm{Kpa}$ at $750^{\circ} \mathrm{C}$

Fig.12. Interface micrograph and EDS line scan between seals and interconnect (a,c); interface micrograph and EDS line scan between seals and anode (b,d). Fig.13. Cell performance used AD40 as anode seals, operated at $750^{\circ} \mathrm{C}$.

Fig.14. The performance stability test result of cell under current density of 0.37 $\mathrm{A} / \mathrm{cm}^{2}$ at $750^{\circ} \mathrm{C}$. 


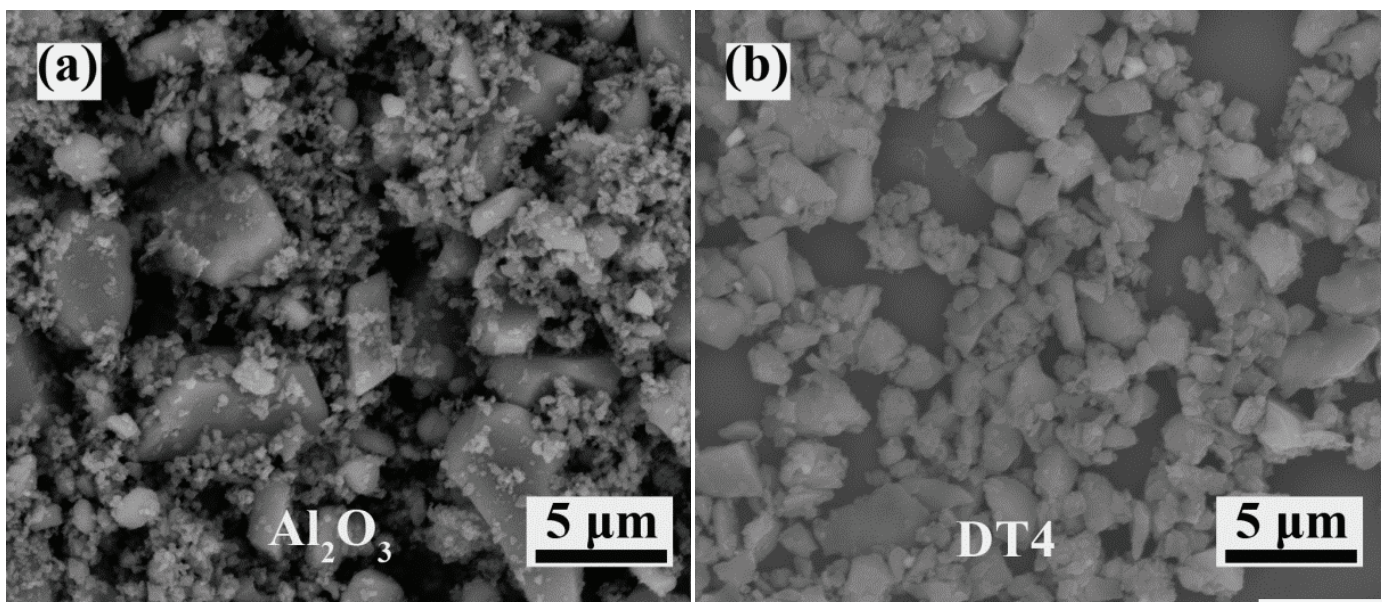

Fig.1. SEM micro morphology of (a) $\mathrm{Al}_{2} \mathrm{O}_{3}$ powder and (b) DT4 glass used for fabrication of composite tape seals. 


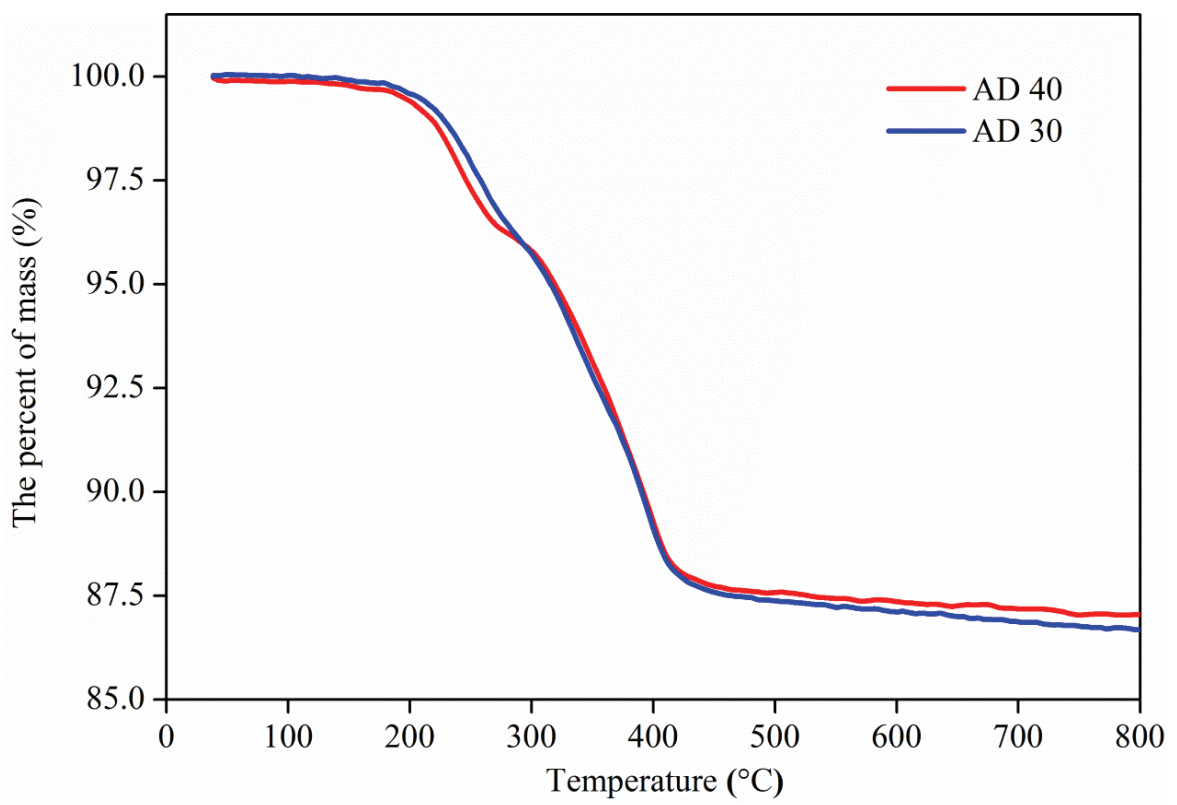

Fig. 2. Thermogravimetric graph of the tape cast AD40 and AD30 samples. 


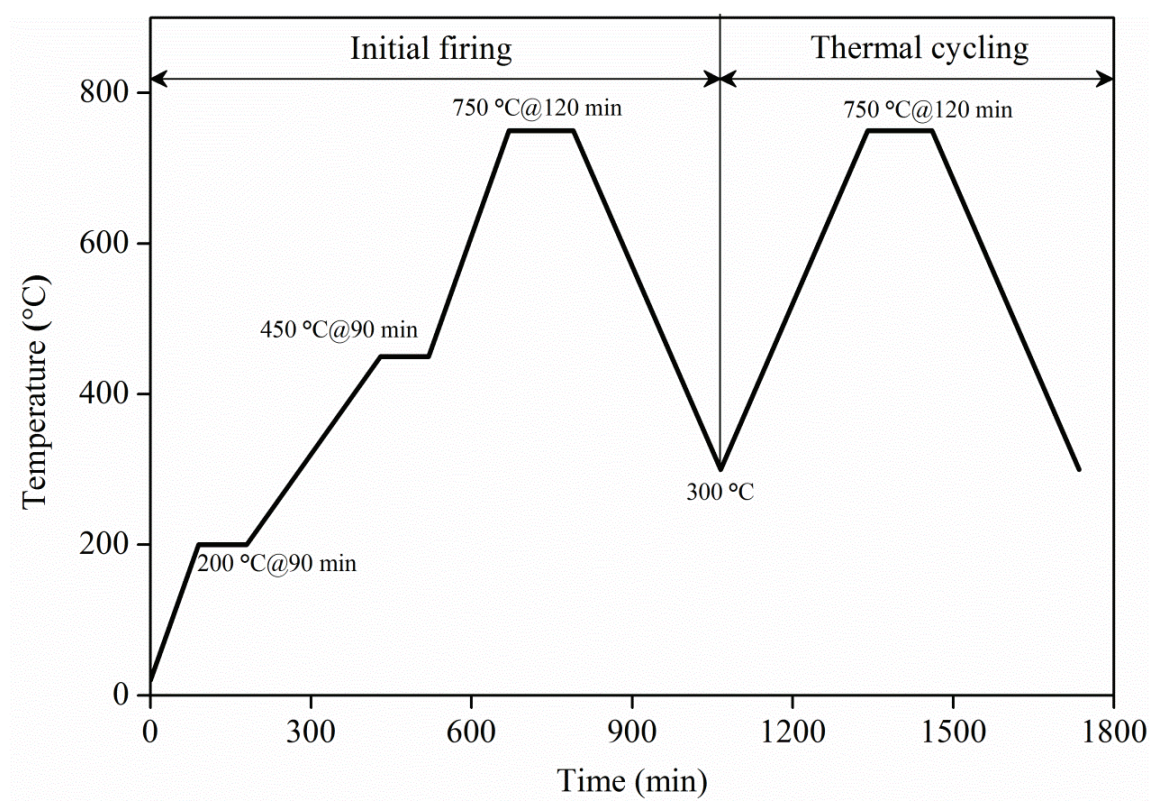

Fig.3. The heat treatment schedule for leakage rates and thermal cycles test. 


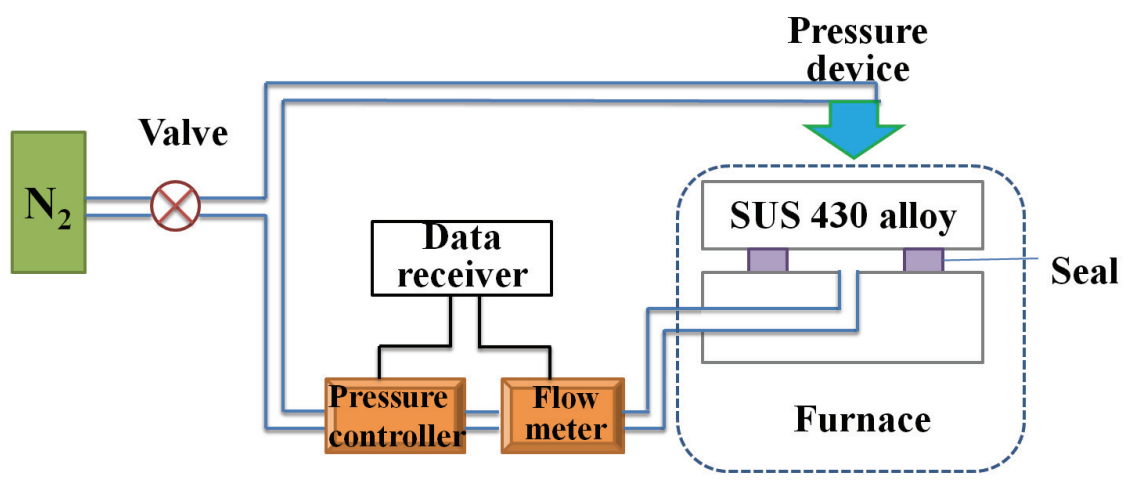

Fig.4. The schematic of the leakage rates test system. 

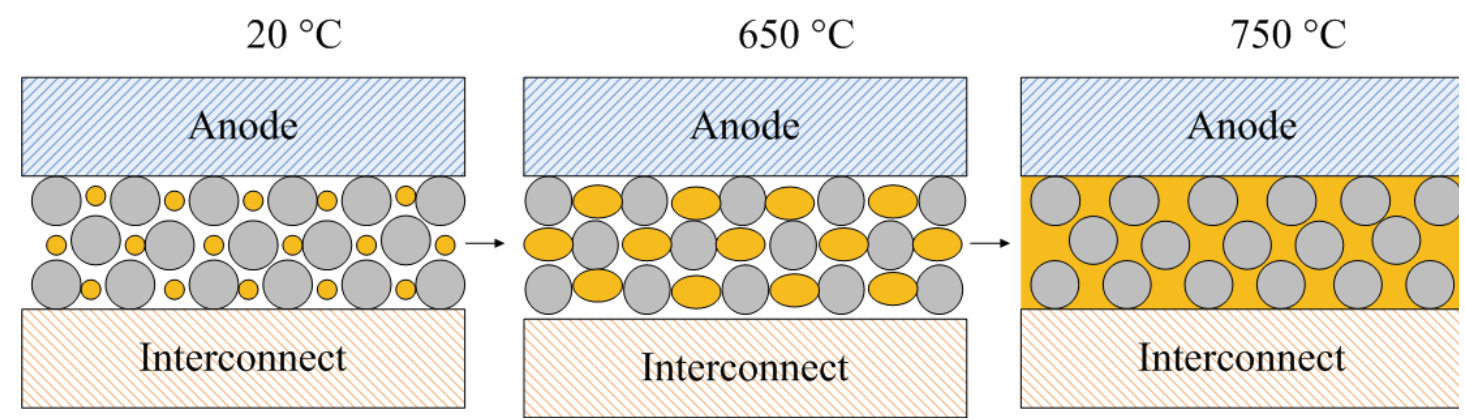

Fig .5 The schematic of $\mathrm{Al}_{2} \mathrm{O}_{3}$-glass composite seals operated at different temperature. 


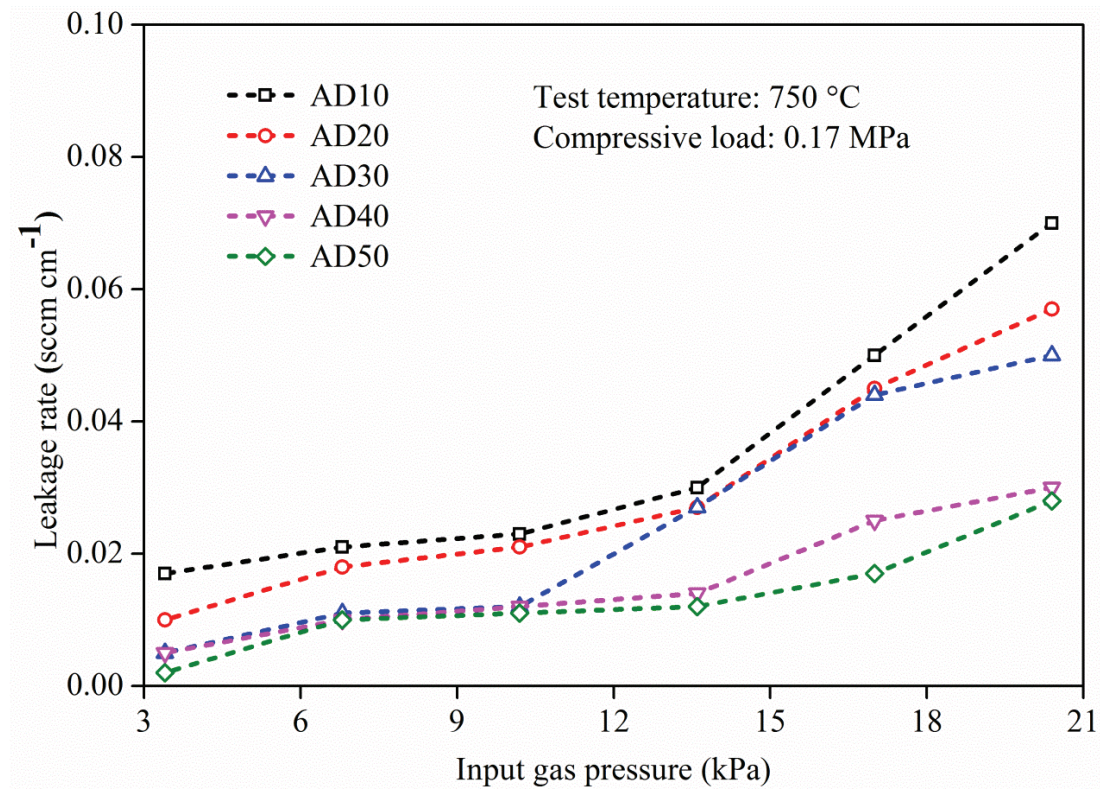

Fig.6 Leakage rates of the seals under different input gas pressure, compressive load $0.17 \mathrm{MPa}$ at $750{ }^{\circ} \mathrm{C}$. 


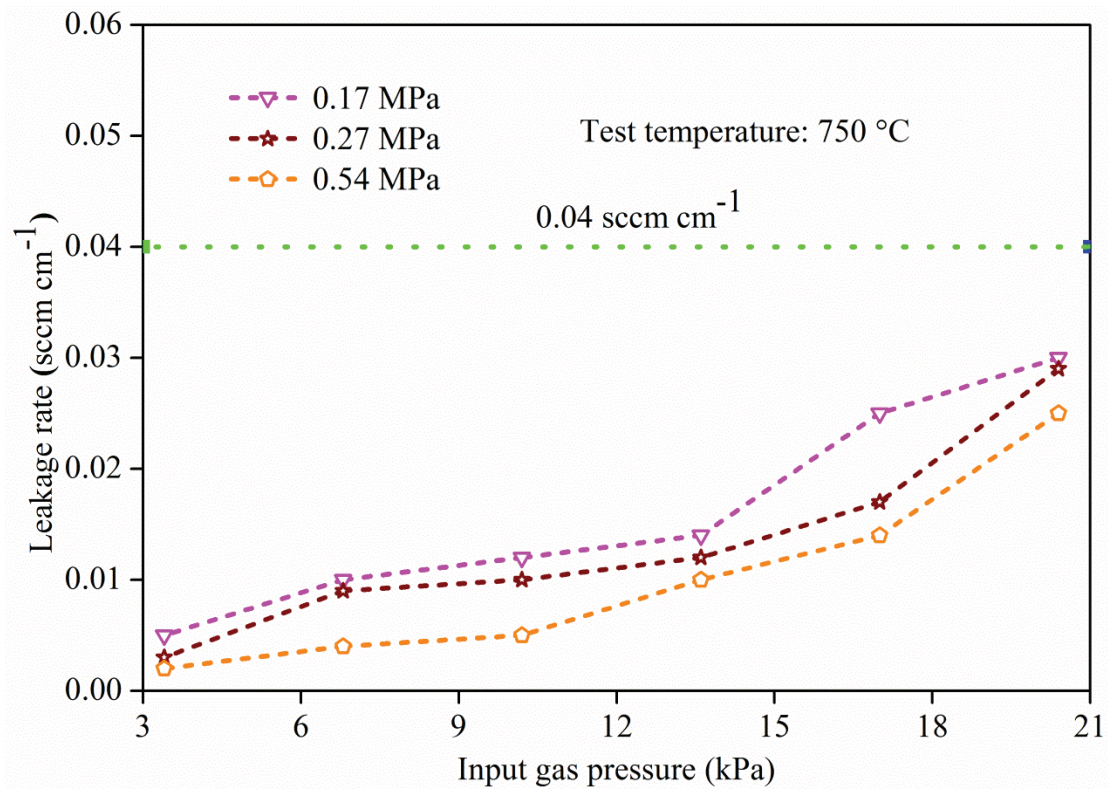

Fig.7. Leakage rates of the $\mathrm{AD} 40$ seals under different compressive load, input gas pressure from 3.4 to $20.4 \mathrm{Kpa}$ at $750{ }^{\circ} \mathrm{C}$. 

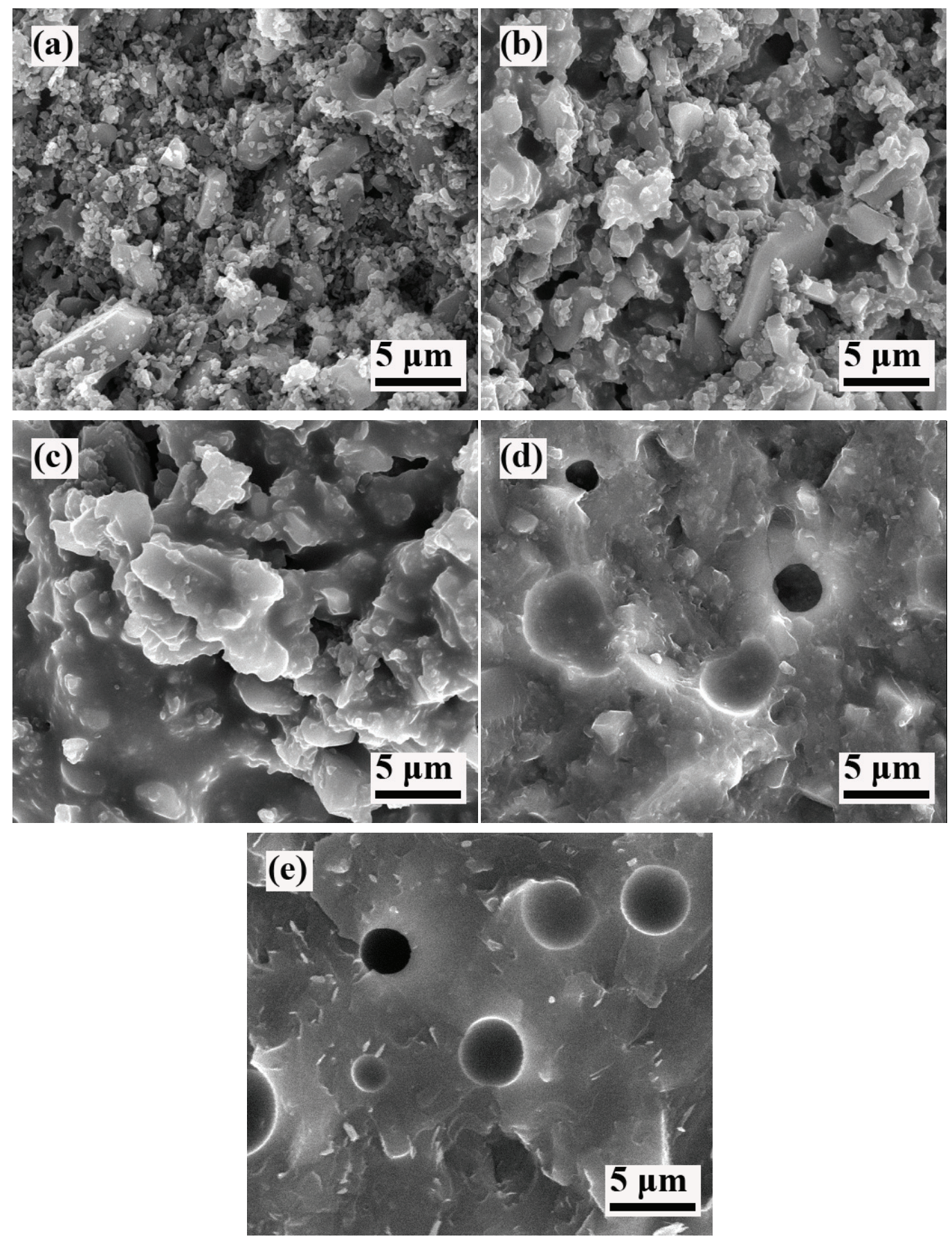

Fig.8. Microstructure of fracture surface for seals under compressive load of $0.17 \mathrm{MPa}$ at $750{ }^{\circ} \mathrm{C}$, (a) $\mathrm{AD} 10$, (b) $\mathrm{AD} 20$, (c) $\mathrm{AD} 30$, (d) $\mathrm{AD} 40$,(e) $\mathrm{AD} 50$. 


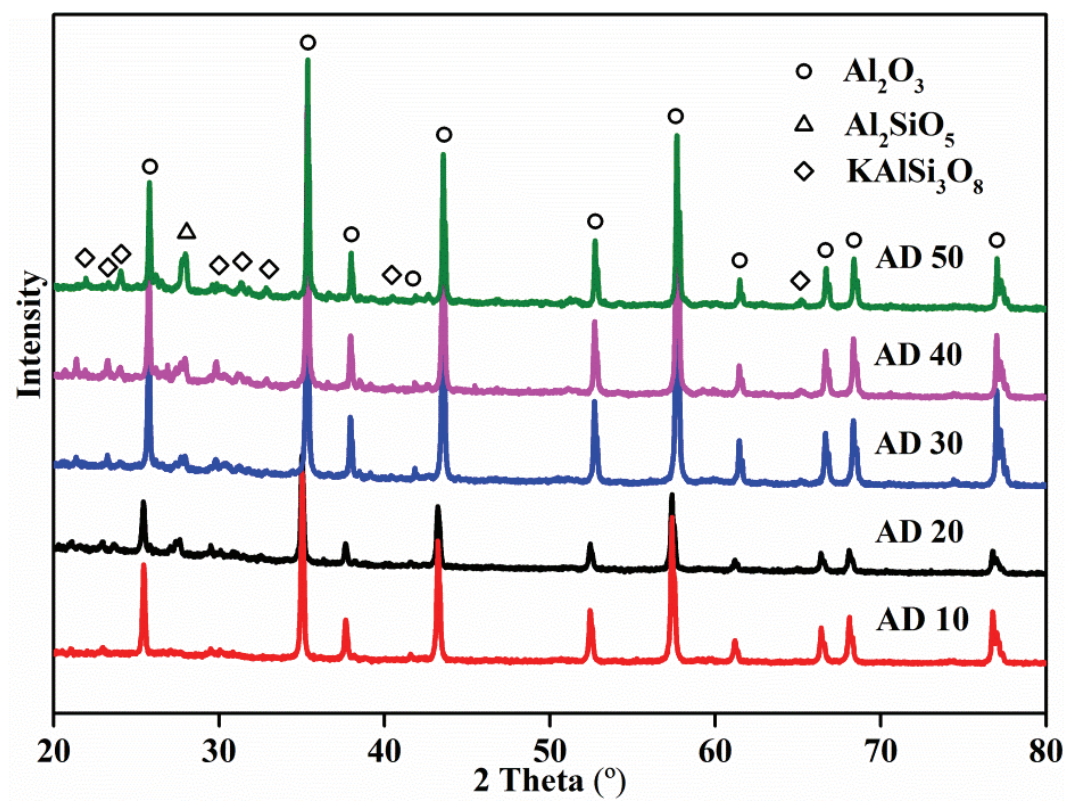

Fig.9. XRD pattern of $\mathrm{Al}_{2} \mathrm{O}_{3}$-based seals with different glass content, heat treated at $750{ }^{\circ} \mathrm{C}$ for $50 \mathrm{~h}$. 


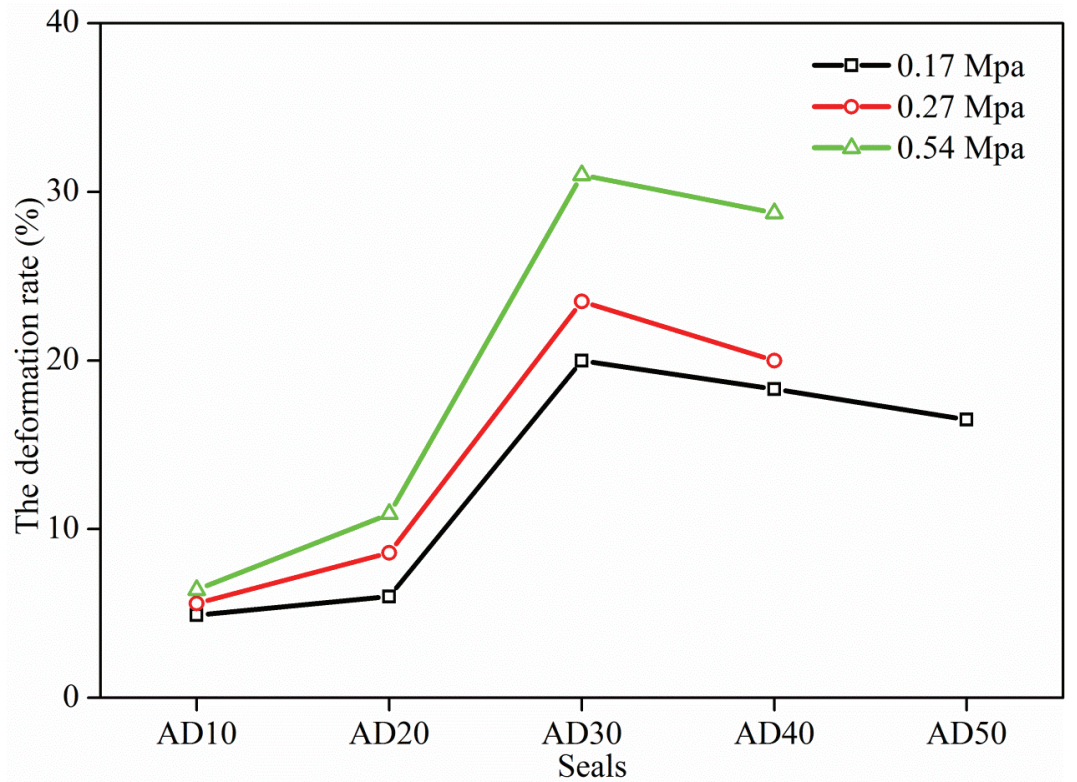

Fig.10. Deformation for $\mathrm{Al}_{2} \mathrm{O}_{3}$-based seals with different glass content under compressive load of $0.17 \mathrm{MPa}$ at $750^{\circ} \mathrm{C}$. 


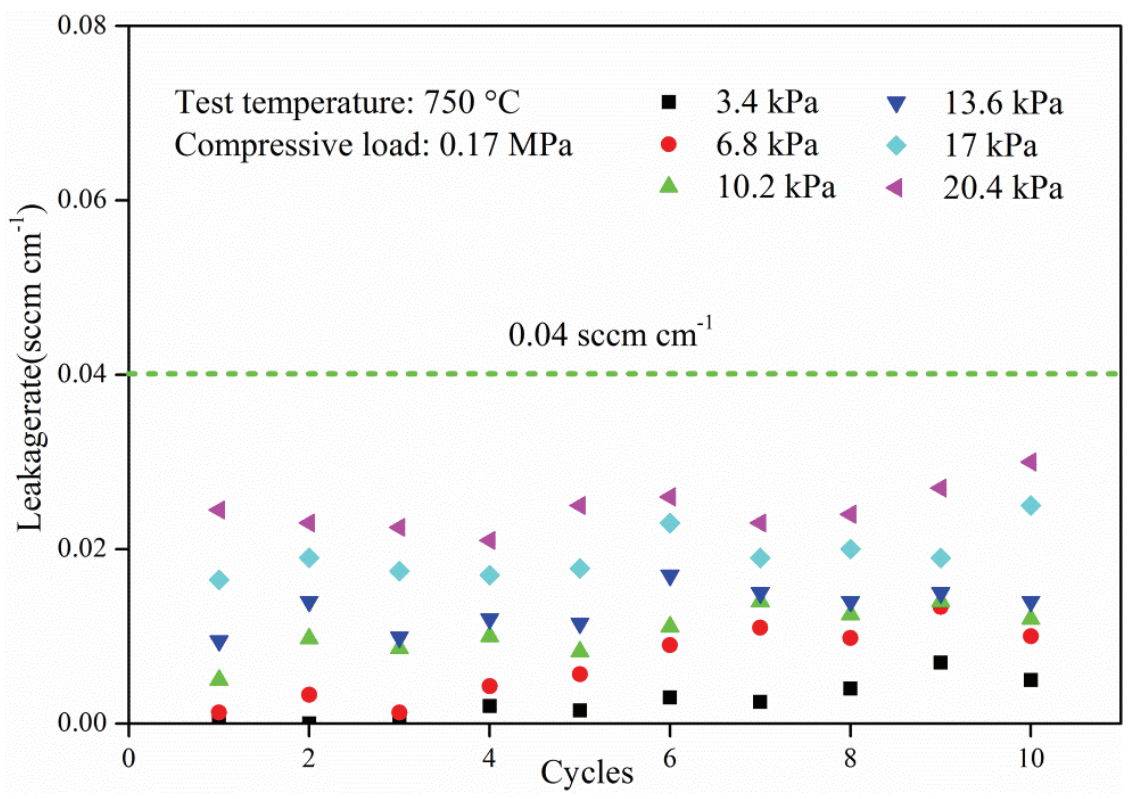

Fig.11. The relationship between leakage rates and thermal cycles for the AD40 seals, compressive pressure of $0.17 \mathrm{MPa}$ and input gas pressure from 3.4 to $20.4 \mathrm{Kpa}$ at $750{ }^{\circ} \mathrm{C}$. 

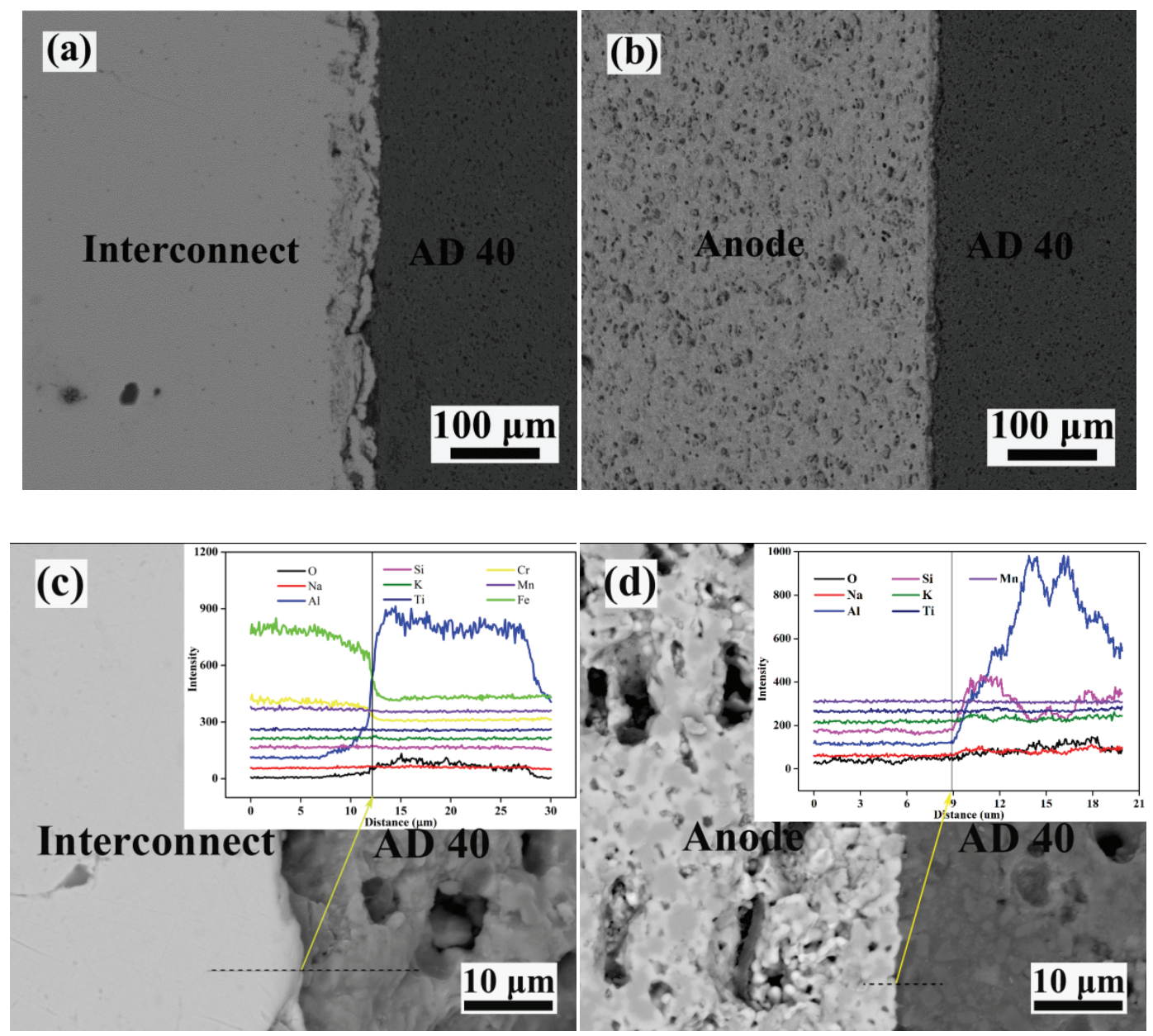

Fig.12. Interface micrograph and EDS line scan between seals and interconnect (a,c); interface micrograph and EDS line scan between seals and anode $(b, d)$. 


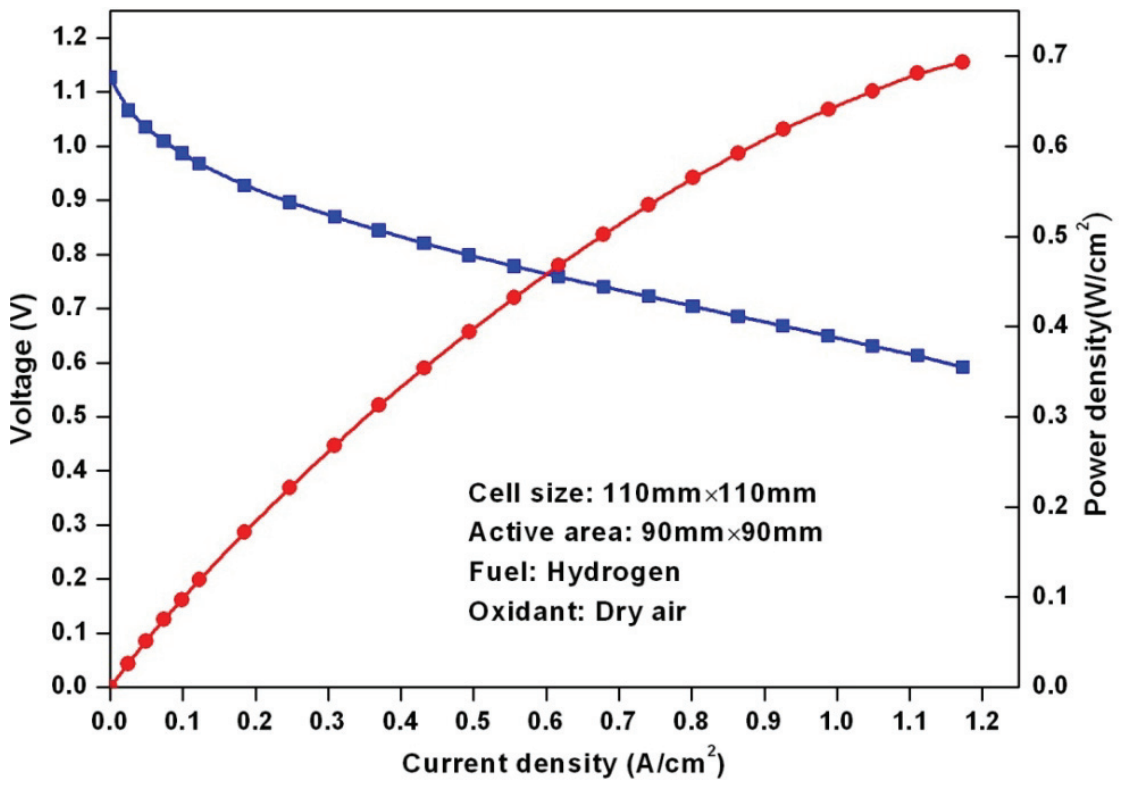

Fig.13. Cell performance used AD40 as anode seals, operated at $750^{\circ} \mathrm{C}$. 


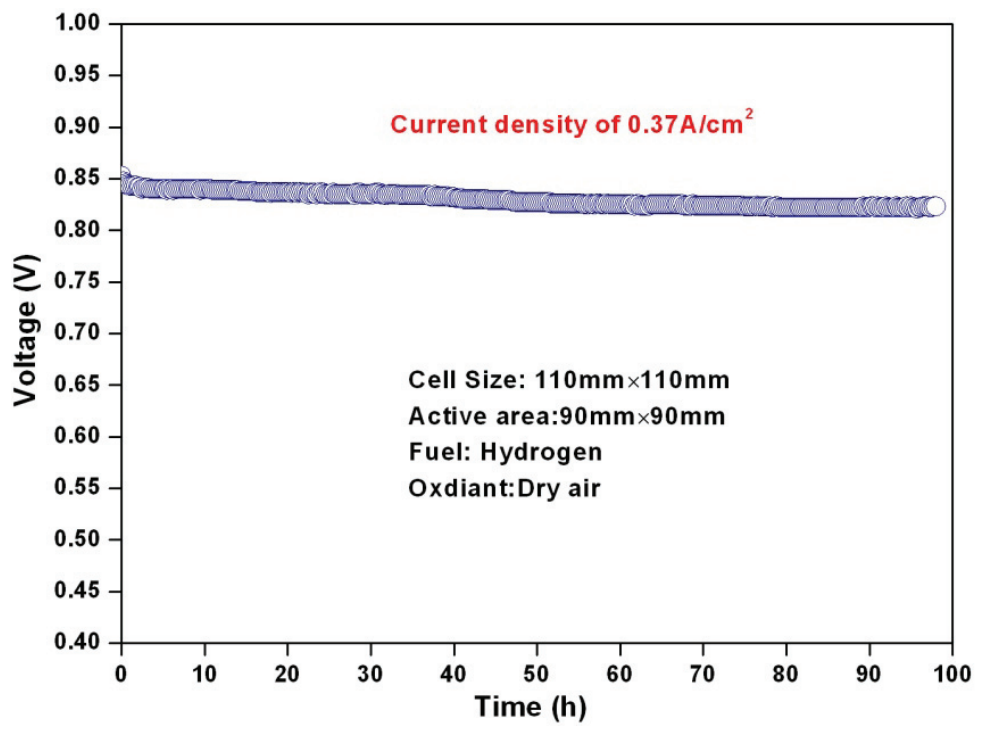

Fig.14. The performance stability test result of cell under current density of $0.37 \mathrm{~A} / \mathrm{cm}^{2}$ at $750^{\circ} \mathrm{C}$. 